\title{
Okul Öncesi Çocuklarda Reklâmın Satın Alma Davranışı Üzerindeki Etkileri"
}

\author{
Sernur KARAOĞLU ${ }^{1}$ \\ Çiğdem BAŞFIRINCI ${ }^{2}$
}

ÖZ: Çocuk pazarl, fiyat duyarlılı̆̆l düşük ve kârlllı̆̆l yüksek bir pazar olarak tüm dünyada büyüme eğilimindedir. Dahası, günümüzde hayatın her alanına nüfuz eden teknolojiler sayesinde, çocukların maruz kaldıkları reklâm sayısı giderek artmaktadır. Buna rağmen, konunun önemi ile kıyaslandığında, çocuklarda reklâm ve satın alma ilişkisini ele alan mevcut çalışmaların sayıca az olduğu görülmektedir. Dahası, alanda Türk örneklem kullanan çalışma sayısı da son derece sınırlıdır. Bütün bu nedenlerle, bu çalışmanın amacı, 4-6 yaş arası anaokulu çocuklarında reklâma maruz kalma ve satın alma tercihi arasındaki karşılıklı iliş̧kileri, deneysel serim kullanarak ortaya koymaktır. Farklı bir kültürel altyapıya, Türk çocuklarına ait bulgular sunacak olması ve bu süreçte geçmişteki çalışmaların çoğundan farklı olarak deneysel serimden faydalanması, bu çalışmanın özgün değerini oluşturmaktadır. Araştırma sonucunda bilişsel gelişimlerinden dolayı 4-6 yaş arası okul öncesi çocukların reklâmın satış amacını kavrayamadığı ve reklâmda gördüğ̈̈ her şeyi gerçek olarak alglladĭ̆ ve reklâmların çocukların satın alma davranışı üzerinde etkili olduğu görülmüştür.

Anahtar Kelimeler: Çocuk, Reklâm, Satın Alma Davranışı, Deneysel Serim, Türkiye.

JEL Kodu: M30, M31, M37

\section{Effects of Advertisement on Purchasing Behavior in Pre-School Children}

\begin{abstract}
With low price sensitivity and high profitability, the children's market has been growing day by day all over the world. Furthermore, due to technology and internet usage that is nowadays prevalent in all areas of life, the number of advertisements that children are exposed to has been increasing. Nevertheless, compared with the prominence of this issue, the number of existing studies dealing with advertising and purchasing relationships in children is still limited. Moreover, the number of studies using the Turkish sample in the field is relatively few. For all of these reasons, the aim of this study is to demonstrate the relationship between advertisement exposure and purchase preference in pre-school children aged 4-6 using experimental method. Using a sample from a different cultural background (Turkey) and using of the experimental method, unlike most of the studies in the past, constitute the original value of this study. As a result of this research, it was seen that children in pre-school aged 4-6 years could not comprehend the purpose of the advertisement because of their cognitive development and that they perceived everything they see in the advertisement as real and that the advertisement has an effect on the children's purchasing behavior.
\end{abstract}

Keywords: Child, Advertisement, Purchasing Behavior, Experimental Method, Turkey

JEL Codes: M30, M31, M37

Geliş Tarihi / Received: 05/06/2018

Kabul Tarihi / Accepted: 28/08/2018

\footnotetext{
* Bu çalışma, KTÜ Sosyal Bilimler Enstitüsü Halkla İlişkiler ve Reklamcılık Ana Bilim Dalı'nda kabul edilen yüksek lisans tezinden uyarlanmıștır.

${ }_{1}^{1}$ Karadeniz Teknik Üniversitesi, sernurkaraoglu@ gmail.com, orcid.org/0000-0002-6284-9179

2 Prof. Dr., Trabzon Üniversitesi, İletişim Fakültesi, cigdem.basfirinci@gmail.com, orcid.org/0000-00031194-9804
} 


\section{Giriş ve Kuramsal Altyapı}

Akademik alanda, reklâm etkileri konusu yetişkinler açısından defalarca ele alınmasına rağmen çocuklar özelinde ele alınışı nispeten sınırlıdır. Reklâmın çocuklar üzerindeki etkileri özellikle Amerika Birleşik Devletleri'nde üzerinde çokça tartışılan bir konu olmuştur. Televizyonun yaygınlaşmasından sonra, özellikle de 1970'li yılların başından itibaren reklâmların çocuklar üzerindeki etkileri konusu daha fazla ilgi çekmiştir. Amerika Birleşik Devletleri'nde de diğer batı ülkelerinde de televizyonun etkileri konusundaki endişeler, araştırmaların yoğunlaşmasının sebebi olmuş ve böylece sosyoloji alanında birçok kuramsal görüşün temeli atılmıştır (Tokgöz, 1979: 103). Reklâmların çocuklar üzerindeki etkilerinden bahsetmeden önce çocuk kavramını ele alacak olursak, çocuğun günümüz modern toplumlarında minyatür yetişkin olarak toplum içerisinde tüketen ve tüketilen nesne konumunda olduğu görülmektedir (Vodinal1, 2016: 205). Tüketime dayalı ekonomik sistemler, çocukların toplumsallaşma süreçlerinde pasif konumda olmalarını hedeflemektedirler. Böylece reklâmlar ile çocukların zihinlerinde marka imajı oluşturmayı ve onlara belli değerleri benimsetmeyi amaçlamaktadırlar. Çocuk, kabul edilen yaş gruplandırılmalarından bağımsız olarak ele alındığında, zihinsel ve bedensel gelişmişlik düzeyleri açısından reklâm mesajlarının güvenilir ve doğru olduğuna inanan tüketici grubudur. Bu nedenle de çocuklar reklâmda aktarılan mesajlara kolayca inanarak benimsemektedir. Analiz yetenekleri gelişmemiş olsa da, çocuklar aileleri üzerinde güçlü etkiler yaratmaktadırlar. Bu nedenle de çocuklar reklâm verenlerin temel hedef kitlesi konumundadırlar (Ertunç, 2011: 29).

Reklâmın çocuklar üzerindeki etkileri çok uzun zamandır konuyla ilgili olan herkesin üzerinde tartıştığ 1 ve tam bir mutabakata varamadığı bir konudur. Karmaşık yapısından ve çok yönlü oluşundan dolayı, çocuk-reklâm konusunu açıklığa kavuşturmanın gerekliliğinden bahseden Kapferer, bunun çözümünün 'model'lemek olduğunu öne sürmüştür. $\mathrm{Bu}$ kapsamda çocuğun manipüle edildiğini öne süren bir model ile bu modelin karşıtı olan çocuğun eleştirme gücüne sahip olduğunu savunan 2 temel modelden bahsetmektedir (1985: 15-36):

Yönlendirilen (manipüle edilen) çocuk modelinde, reklâmın çocuklar üzerindeki etkisinin oldukça büyük olduğu kabul edilmektedir. Bu modele göre çocuk, iki şekilde etki altına alınabilir; öğretme ve bilinçaltını etkileme. Eleştirebilen çocuk modeli ise, reklâm dünyasının etkili olduğu bir modeldir. Bu model, 1978 yılında yapılan Scrivener Komisyonu'nun reklâm ve çocuk ilişkisini incelediği araştırmaya model olmuştur. $\mathrm{Bu}$ araştırmanın sonucuna göre çocuk, hızlı görüntüler karşısında gerçek ve eleştirel bir tavır ortaya koyabilmektedir. Eleştirebilen çocuk modeline göre, yetişkininin küçültülmüş hali olarak görülen çocuk, reklâmların yaratacağı etkiyle baş edebilecek bir kapasiteye sahiptir. Çocuk ve reklâm konusunda bu iki model dışında yine Kapferer'in aktardığı bir başka model daha vardır. $\mathrm{Bu}$ modelin 1950'lerde seçim sonuçlarını değerlendirebilmek için yapılan sosyolojik anketler sonucunda doğduğu görüşü 
bulunmaktadır. Bu anketler yapılmadan önce kabul edilen düşünce kitle iletişim araçlarının herkes üzerinde aynı etkiyi yaptı̆̆ı yönünde olmuştur. Anketlerin sonuçlarına göre ise, kitle iletişim araçlarında yapılan seçim kampanyaları her seçmenin tercihini etkilememiştir. Bu nedenle kitle iletişim araçlarının etkisi yeni bir tartışma konusu olmuştur. Artık geçerli olan düşünce, 'kitle iletişim araçları aracılığıyla kitlelere iletilen bazı mesajlar, bazı koşullarda ve bazı kişiler üzerinde çeşitli etkiler yaratabilir' şeklindedir. Chalvon ve diğerlerinin yaptığı bir araştırmaya göre kitle iletişim araçlarından televizyon incelenirken, televizyon dişında birçok şeyin, televizyonun bulunduğu ve izlendiği ortamın koşullarının da incelenmesi gerekmektedir. Bu koşullar, ailenin televizyon izlerken bulunduğu ortamın sıcak ya da soğuk olması ile ailenin içinde yer aldığı sosyal ortam, ailenin kültürel düzeyi, ailenin değer ve normları gibi birçok faktörü içermektedir. Sonuç olarak, ailenin ortamının koşullarına bağlı olarak oluşan bir model olan "ailesel filtre modeli" gelişmiştir (aktaran: Kapferer, 1985: 23). Bu modeli reklâmın çocuklar üzerindeki etkileri bağlamında ele almak gerekirse şöyle bir örnek verilebilir; aynı reklâmı izleyen iki farklı çocuk, reklâmdaki ürünü aynı düzeyde istemesine rağmen, çocuklardan biri bu isteğini hemen anne-babasına söylerken, diğer çocuk söylememektedir. Bu durum, isteğini söylemeyen çocuğun annebabasının bu konuda ne tepki vereceğini bilmesinden ve o ürünü satın almayacakları konusunda fikrinin olmasından kaynaklanmaktadır. Çocuklar ailelerinin tutumlarının farkında olarak, isteklerini sınırlandırabilmektedir. $\mathrm{Bu}$ nedenle reklâmın etkisi her çocuk için aynı olmamaktadır. Çocuk ve reklâm konusunda incelenen bu üç modeli kapsayan temel bir model ortaya koyan Kapferer, bu modelin çocuğun reklâmla karşılaştığı sırada oluşan psikolojik süreci incelediğini ifade etmektedir. $\mathrm{Bu}$ modelin amac1, çocuğun reklâm mesajını algılarken bilinçli veya bilinçsiz geçirdiği işlemleri çözümlemektir. Bütünleyici olan "ayartma-inandırma" modeli, reklâm mesajının çocuk tarafından işlenmesine ilişkin olarak, zihinsel işlemlerin duygusal tepkilere yol açtığını iddia etmektedir. $\mathrm{Bu}$ bazen zihinsel işlemleri kesintiye uğratmak, bazen de daha kolaylaştırıcı biçimde onları ortaya çıkartmak şeklinde olabilmektedir. Ayartma- inandırma modelinde, zihinsel ve duygusal süreçler birbirini izlemekte ve etkilemektedir. $\mathrm{Bu}$ süreç içinde oluşacak bir eleştirel tavır olumsuz tepkiye yol açmaktadır. Çocuğun reklâmla karşılaşmasının ardından, reklâmı yapılan ürün veya marka konusunda akılda kalanlar, çocuğun gelişim düzeyine göre farkl1lık gösterebilmektedir. Mesela altı yaşın altındaki çocukların daha fazla şeyi gözden kaçırdığ bilinmektedir. Çocuğun reklâm mesajı ile ilgilenme derecesi, mesajın çocuğun zihnine ne kadar yerleşeceğini belirleyen ilk etken olmaktadır. Reklâmı izlediği sırada çocuk duygusal tepkiler veriyorsa, ürünün biçimi, özellikleri ve markası daha az aklında kalacaktır. Bu durumda da reklâm sonrasında çocuğun aklında daha çok reklâmın müziği ve sloganı gibi biçimsel özellikler kalacaktır. Bu nedenle reklâmcılar bir reklâmı oluştururken, zihinsel ve duygusal algılara verecekleri mesajlarda dengeli olmaya çalışmaktadırlar. 
Geleceğin tüketicileri olan çocuklar, markalar ve pazarlamacılar için önemli bir konuma gelmiştir. Pazarlama faaliyetlerinde özellikle çocuk tüketicilere yönelik artışı, McNeal üç sebebe dayandırmaktadır. Bunlardan ilki, zaman içerisinde çocukların harçlık miktarlarının ve harcama özgürlüklerinin artmış olması; ikincisi, çocukların geleceğin tüketici pazarını oluşturuyor olmaları ve bu sebeple erken yaşta marka ile tanışan çocukların gelecekte markaya sadık olacağı düşüncesi, sonuncusu ise, çocukların ailenin satın alma kararlarında giderek daha fazla rol oynar hale gelmeleridir (1999: 16). Son zamanlarda ataerkil ve anaerkil aile kavramlarının yanı sıra çocukerkil aile kavramının da sıç̧a kullanılır hale gelmesi bu durumun bir göstergesi niteliğindedir. Fakat konunun önemi ile kıyaslandığında, alandaki çalışmaların göreceli olarak sınırlı olduğu görülmektedir. Konunun öneminden yola çıkılarak bu araştırmada, okul öncesi çocuklarda reklâmın satın alma davranışı üzerindeki etkileri incelenmiştir. Çalışmanın devamında öncelikle konuya ilişkin literatür taraması sunulmuş, ardından çalışmanın yöntemi ve analiz süreci anlatılmıştır. Son olarak elde edilen bulgular alandaki geçmiş çalışmalarla karşılaştırılarak sonuçlar genel bir değerlendirme şeklinde sunulmuştur.

\section{Literatür Taraması}

Literatüre bakıldığında, çocuk ve reklâm ilişkisini farklı açılardan ele alan birçok çalışmaya rastlanmaktadır. Yapılan çalışmaların genel olarak televizyon reklâmlarının çocuklar üzerindeki etkisi konusuna yoğunlaştı̆̆ görülmektedir (Clancy- Hepburn vd., 1974; Goldberg ve Gorn, 1974; Atkin, 1975; Adler, 1977; Goldberg ve Gorn, 1977; Goldberg vd., 1978; Brody vd., 1981; Roedder vd., 1983; Gorn ve Florsheim, 1985; Aitken vd., 1987; Lewis ve Hill, 1998; Verma ve Kapoor, 2004; Boyland ve Halford, 2013). Farklı kültürlerden bulgular da içeren bu çalışmalardan çıkan genel sonuç, televizyon reklâmlarının çocukların başta yiyecek seçimleri olmak üzere tüketecekleri diğer ürünler konusunda da yönlendirici olduğu ve reklâmların çocukların marka tercihlerine etki ettiği, hatta çocukların yetişkin olduklarında kullanacakları ürünler ve markalarla ilgili algılarını etkilediği yönünde olmuştur. Literatürde ayrıca çocuk ve reklâm ilişkisini obezite açısından ele alan çalışmalara da rastlanmaktadır (Halford vd. 2004; Aktaş Arnas, 2006; Halford vd. 2007; Guran vd., 2010; Bakir vd., 2013; Jenkin vd., 2014). Bu çalışmaların önemli kısmı, reklâmların çocukların gıda ürünü tercihlerinde etkili olduğunu ve çocuk obezitesi ile reklâmlar arasındaki ilişkinin varlığını ortaya koymaktadır. Yapılan bazı çalışmalarda da araştırmacılar çocuk ve reklâm ilişkisini toplumsal cinsiyet genelinde ve cinsiyet değişkeni üzerinden ele almışlardır (Chernin, 2008; Bakir ve Palan, 2010).

Reklâmın çocukların satın alma tercihine olan etkisini inceleyen çalışmaların ise genel olarak sınırlı olduğu söylenebilir (Burr ve Burr, 1977; McNeal ve Yeh, 1997; Farooq vd.,2010; Hameed vd., 2014). Bu çalışmalar çocukların reklâmda gördükleri ürünleri satın almak istediğini ve özellikle yiyecek reklâmlarının 
çocukların tüketim alışkanlıklarını etkileyerek daha fazla tüketime sebep olduğunu ortaya çıkarmıştır.

Reklâm ve çocuk ilişkisini incelerken bazı araştırmalar diğerlerinin aksine daha özel bir yaş grubu olan okul öncesi çocuklar üzerine yoğunlaşmıştır (Butter vd., 1981; Levin vd., 1982; Stephens vd., 1982; Borzekowski ve Robinson, 2001; Connor, 2006; Ülger, 2016; Sramova ve Pavelka, 2017).Bu çalışmalarda daha çok okul öncesi çocukların programlar ile reklâmları ayırt edip edemedikleri, medya alışkanlıkları ve reklâm mesajlarını nasıl algıladıkları ele alınmıştır. Sonuçlar okul öncesi çocukların televizyon programları ile reklâmları birbirinden ayırt edebildiğini, televizyonun hayatlarında önemli bir yeri olduğunu ve televizyon reklâmlarının tüketim alışkanlıklarını etkilediğini ortaya koymuştur.

Goldberg ve diğerlerinin 1978 'de yaptığı bir çalışmada 6 yaşındaki çocuklarla çalışılmış ve çocuklar üç gruba ayrılmıştır. Bir gruba şekerleme reklâmları, bir gruba sosyal amaç taşıyan ve meyve, sebze, süt ve yumurtanın faydalarından bahseden reklâmlar, diğer gruba da hiçbir reklâmın yer almadığı bir televizyon programı izletilmiştir. Daha sonra çocuklara, bir senaryo anlatılmış ve bu senaryoda ebeveynlerinin altı günlük bir tatile çıktıklarını düşünmelerini ve o sırada onlara kendilerinin bakacaklarını ifade eden araştırmacılar, çocuklardan bu altı günlük sürede onlara neler yedirebileceğini bilmeleri gerektiğini bu nedenle de gösterecekleri ürünler için hangilerini istiyorlarsa seçmeleri istenmiştir. Çocuklara her gün için altı çeşit ürün gösterilmiş, bunlardan üçü besleyici ve sağlıklı üçü ise besleyici değeri düşük şekerli ürünlerden belirlenmiştir. Çocuklardan bu altı çeşit üründen her gün için üç çeşit seçmeleri istenmiştir. Böylece çocuklara toplamda 18 çeşit ürün seçme olasılığı tanınmıştır. Çalışma sonucunda görülmüştür ki, reklâm izlemeyen kontrol grubundaki çocuklar ortalama 10 çeşit; şekerleme reklâmını izleyen çocuklar ortalama 12,5 çeşit ve sosyal amaçlı reklâmı izleyen gruptaki çocuklar ortalama 8,7 oranında şekerli ürünlerden seçmişlerdir. Bu sonuçlar çocukların seçimlerinde, aldıkları mesajların etkisinde olduklarını göstermiştir.

Brody ve diğerlerinin 1981'de yaptığı çalışma, çocuklara yönelik televizyondaki yiyecek reklâmlarına, ailece yapılan bakkal alışverişlerine ve anne çocuk etkileşimlerine odaklanmıştır. Burada ilk çalışmada çocukların televizyon reklâmlarından etkilenip etkilenmediği araştırıldıktan sonra ikinci çalışmada ise annelerin çocuklarıyla izledikleri reklâmlardaki besinler hakkında alternatif bilgileri sağlayıp sağlamadığı ortaya koyulmaya çalışılmıştır. Çalışma iki gruptan oluşmuştur. 57 anne ve çocuğun olduğu çalışmada, anne-çocuk çiftleri rastgele iki gruba dağıtılmıştır. Çocukların satın alma girişimleri ise, bu araştırma için oluşturulmuş bir mağazada gerçekleşmiştir. Deney sonucunda, iki önemli noktaya rastlanmıştır. İlk olarak, reklâma maruz kalan çocukların kontrol grubundaki diğer çocuklara göre reklâmını gördükleri ürünleri alma eğilimini daha fazla gösterdiği fark edilmiştir. İkinci bir bulguda ise, annelerin çocuklarıyla sık sık televizyon reklâmları hakkında görüştüklerini belirtmelerine rağmen aslında annelerin 
reklâm bilgileri ve reklâmı yapılan ürünlerin besin değerleri hakkında bir bilgi sağlayamadıkları ortaya çıkmıştır.

Levin ve diğerleri ise 1982 'de yaptıkları bir çalışmayla okul öncesi çocukların televizyon reklâmları farkındalığını incelemişlerdir. Yaşları 3-5 arasında değişen çocukların reklâm ve televizyon programı şeklinde kaydedilmiş videoları izleyip doğru bir tanımlama yapıp yapmadıkları incelenmiştir. Tanımlamaların doğru yapılması için hem işitsel hem görsel kodlamalar kullanılmıştır. Çocuklara izletilen kısa videoların ardından çocuklardan bu videonun program mı yoksa reklâm mı olduğunun tanımlanması istenmiştir. Çalışmanın sonuçları, üç yaşından küçük, okul öncesi çocukların program ve reklâm kavramlarını anladıklarını ve ikisi arasında ayrım yaparken bu kavramları kullanabileceğini göstermiştir. Araştırmada ayrıca yaş faktörü önemli bir rol oynamış, 5 yaşındaki çocukların diğer yaş gruplarındaki çocuklara göre daha iyi tanımlamalar yaptığı belirlenmiştir.

Stephens ve diğerleri 1982 yılında yaptıkları çalışmada okul öncesi çocukların, televizyon programları ile reklâmları ayırt edip edemediklerini araştırmışlardır. Geliştirilen bir model ile çocukların üzerinde deney yapılmış, \%82 oranında doğruluk payı ile okul öncesi yaş grubunda bulunan çocukların televizyon programları ile reklâmları birbirlerinden ayırt edemedikleri sonucuna varılmıştır.

Çocukların televizyon reklâmlarından ne düzeyde etkilendiklerini ortaya koymak amacıyla Roedder ve diğerlerinin 1983 'de yaptıkları çalışmada, 5-8 yaş ve 9-13 yaş aralığındaki iki farklı gruba yeni bir ürünü tanıtan reklâm filmi izletilmiştir. Çocuklardan bu ürününün bulunduğu kategoride bulunan diğer ürünler ve bu yeni ürün hakkındaki düşüncelerini belirtmeleri ve ürünler arasından tercihte bulunmaları istenmiştir. 9-13 yaş grubundaki çocuklar seçimleri sırasında reklâmı yapılan ürüne yönelik fazla tercihte bulunmazken, 5-8 yaş grubundaki çocuklar tercihlerini reklâmını izledikleri üründen yana kullanmışlardır. Araştırmacılar iki grup arasındaki farkın çocukların bilişsel gelişim düzeylerinin aynı olmamasından dolayı oluştuğunu belirtmişlerdir.

Borzekowski ve Robinson 2001'de televizyon reklâmlarının okul öncesi çocukların yemek tercihleri üzerindeki etkisini ortaya koyan bir deney gerçekleştirmişlerdir. 2-6 yaş arası rastgele seçilmiş 42 okul öncesi çocuktan oluşan bu deneyde, iki gruptan birine reklâmın saklı olduğu popüler bir çizgi film izletilmiş diğer gruba ise aynı çizgi film reklâmın hiç olmadığı haliyle izletilmiştir. Çizgi filmde saklı olan reklâmlar çocukların sıkça kullandığı ürünler olan meyve suyu, sandviç, mısır gevreği, atıştırmalık kek ve şeker gibi ürünlerden oluşturulmuştur. Ürünlerin her birinin gösterildiği zaman 30 saniye olarak belirlenmiştir. Deney sonunda araştırmacı asistanı tarafından çocuklarla onların medya alışkanlıklarına dair kısa bir sohbet yapılmış ve çocuklara bir takım resimler gösterilip iki resmi eşleştirmeleri istenmiştir. Sonuç olarak reklâmın gömülü olduğu çizgi filme maruz kalan çocukların reklâma maruz kalmayan diğer 
gruba göre, seçtiği resimlerde çizgi filmde gördüğü ürünleri seçtiği gözlemlenmiştir.

Verma ve Kapoor 2004'deki çalışmasında çocukların erken çocukluktan erken ergenlik dönemine kadar televizyon reklâmlarından aldıkları etkileri ve bu süreçte ve reklâmların ebeveyn-çocuk etkileşiminin rolüne olan olası etkilerini değerlendirmeyi amaçlamıştır. Bu amaçla çalışmada farklı gelir gruplarından ve farklı cinsiyetlerden seçilen çocuklar ve ailelerine anket uygulanmıştır. Araştırmada ebeveynler, sekiz yaşın üstündeki çocukların ailenin satın alma kararı üzerindeki artan rollerini kabul ettiklerini ortaya koymuştur. Hem çocuklar hem de ebeveynler televizyon reklâmlarının çocukların satın alma kararı üzerinde etkili olduğunu anlamışlardır. Ayrıca çocuğun yaşının artmasıyla paralel olarak satın alma davranışında televizyon reklâmlarından etkilenme eğiliminin azaldığı gözlemlenmiştir.

Türkiye'de de bu alanda daha çok marka ve reklâmların çocukların beslenme alışkanlıkları üzerindeki etkisi araştırılmıştır (Tokuç, 2009; Günlü ve Derin, 2012; Kurt ve Altun, 2014). Araştırma bulguları göstermektedir ki, çocukların büyük çoğunluğu reklâmlardan etkilenmekte ve reklâmlarda gördükleri yiyecekiçecekleri hemen alıp tüketmek istemektedirler. Bu çalışmalarda reklâmların çocukları fast-food tüketimine yönlendirerek onların beslenme alışkanlıklarını olumsuz yönde etkilediği sonuçlarına da varılmıştır. Televizyonun, dolayısıyla da reklâmların çocuklar üzerindeki etkilerini araştıran çalışmalar da mevcuttur (Tokgöz, 1979; Büyükbaykal, 2007; Karaca vd., 2007; Ünal ve Durualp, 2012). $\mathrm{Bu}$ çalışmaların bulguları, çocukların reklâmlardan bilgi edindiklerini, reklâmda gördükleri ürünleri ebeveynlerinden istediklerini, ayrıca çocukların reklâmları sevdiklerini ve inandırıcı bulduklarını belirtirken reklâmların olumsuz olarak çocukların tüketim ve beslenme alışkanlıklarını da etkilediklerini ortaya koymuştur. Literatürde yer alan örneklerde de görüldüğü gibi reklâmlar çocukları etkilemekte ve tüketim alışkanlıklarına etki ederek onları satın alma davranışına yönlendirmektedir. Özellikle küçük yaştaki çocukların reklâmlardan daha fazla etkilendikleri ve satın alma davranışında reklâm etkisiyle hareket ettikleri de bilinmektedir.

Fakat literatüre yansıdığı kadarıyla ülkemizde anaokulu çocuklarında reklâmın satın alma davranışı üzerindeki etkisini inceleyen bir başka çalışmaya rastlanmamıştır. Bu özgün değerden yola çıkarak, bu çalışmanın amacı reklâmın anaokulu çocuklarının satın alma davranışı üzerindeki etkisini deneysel serim yardımıyla ortaya koymaktır.

\section{Metodoloji}

Araştırmada temel olarak nicel yöntemden faydalanılmış ve test sonrası kontrol gruplu deneysel serim uygulanmıştır. Deneysel serimler, dış değişkenlerin etkilerini kontrol altına alarak bağımlı değişkene etki eden faktörlerin sonuçlarını ölçmek amacıyla yapılan serimlerdir (Kurtuluş, 2006: 257-267). Bu araştırmada 
kontrollü deneysel serimlerden, test sonrası kontrol gruplu deneysel serim kullanılmış, denekler deney ve kontrol gruplarına tesadüfi olarak atanmış ve böylelikle geçersizlik kaynaklarından biri olan seçim etkisi ortadan kaldırılmıştır. Deneysel serimler için diğer içsel geçersizlik kaynakları, geçmişin etkisi, olgunlaşma etkisi, test etkisi ve araç etkisidir. Bu çalışma sırasında deneklere araştırmanın amacı açıklanmadığı için test etkisi, çalışma boyunca tek bir ölçme aracı (gözlem) kullanıldığı için de araç etkisi ve deney öncesinde bir ölçme olmadığı için test etkisi ortadan kaldırılmıştır (Kurtuluş, 2006: 256-263; Nakip, 2003: 143).

Kuramsal altyapı ve farklı ülkelerdeki geçmiş çalışmaların bulgularından yola çıkarak, henüz bilişsel gelişim düzeylerini tamamlamamış okul öncesi çocukların reklâmdan etkilenme oranlarının yüksek olacağı tahmin edilmiş ve araştırmanın evreni olarak Trabzon'da bulunan okul öncesi grubundaki 4-6 yaş arası çocuklar seçilmiştir. Araştırma için gereken yasal izinler MEB'den alınmış, ancak, teknik ve finansal diğer kısıtlar nedeniyle kolayda örneklem yöntemi benimsenerek araştırma kapsamında bir özel kreş, iki özel anaokulu ve üç devlet anaokulu seçilmiştir. Dolayısıyla çalışma, anaokuluna devam eden 4-6 yaş arasındaki 209 çocuk üzerinde gerçekleştirilmiştir. Bu 209 çocuğun 102'si deney 107'si ise kontrol grubunda yer almaktadır. Deney ve kontrol grupları, gidilen okullarda araştırmacı tarafından tesadüfi olarak belirlenmiştir. Araştırma süreci iki aşamadan oluşmaktadır. İlk olarak deney ve kontrol grubuna izletilecek çizgi film ile deney grubuna izletilecek reklâm filmlerine karar verilmiştir. Bu aşamada çizgi filmin seçilmesinde, bu yaş grubu için uygun değerler eğitimi göz önüne alınarak bir film seçkisi hazırlanmıştır. Ardından bu filmlerin içinden kaygı, korku, şiddet gibi olumsuz nitelikteki duyguları barındıran filmler elenmiş ve sevgi, empati, mizah gibi olumlu duygular içeren filmler seçilmiştir. Sonrasında, bu filmler, alanında uygun eğitim görmüş anaokulu öğretmenlerinin görüşüne sunulmuş ve filmlerin içinden çocuklar için en uygun olduğu düşünülen film seçilmiştir. $\mathrm{Bu}$ film, Pixar firmasına ait "Birds on a Wire" adlı 3 dakika 14 saniye süren bir filmdir. Ardından araştırmada deneklere sunulacak olan ürünün seçim süreci tamamlanmıştır. Bu ürün seçilirken, Türkiye'de çocukların ana akım televizyon kanallarında ve çocuk kanallarında daha önce reklâmını görmedikleri bir ürün olmasına dikkat edilmiştir. Böylelikle deneysel serimin içsel geçerliliği yükseltilmeye çalışılmış (Kurtuluş, 2006: 257-258) ve geçmişin etkisi (Kurtuluş, 2006: 256) de kontrol altında tutulmaya çalışılmıştır.

Test edilecek ürün seçilirken, geçmişin etkisini azaltıp, içsel geçerliliği arttırmak amacıyla Türkiye'de çocukların televizyon kanallarında daha önce reklâmını görmedikleri bir ürün olmasına dikkat edilmiştir. Araştırmanın dizaynı gereği, deney grubuna gösterilecek reklâm filmindeki ürünün, daha sonra çocukların satın alması için stantta sunulması gerekmektedir. Bu yüzden piyasada bulunan fakat her markette satılmayan bir ürün olan, dünyada sıkça reklâmı yapılması ve birçok ülkede satışı bulunmasına rağmen Türkiye'de ise sınırlı yerlerde satın alıma sunulan ama çoğu çocuğun ekseriyetle tanımadığı bir şekerleme markası olan 
M\&M's'in draje şekeri seçilmiştir. Ürün belirlendikten sonra ilgili veri tabanında ve başta Youtube olmak üzere çeşitli internet kaynaklarında yer alan ürün ile ilgili reklâm filmleri tek tek izlenmiş ve 4-6 yaş grubu için uygun olduğu düşünülen bir tanıtım/reklâm filmi seçilmiştir. Bu reklâm filminin başına ve sonuna montaj teknikleri kullanılarak deneklere satışa sunulacak olan ürün paketinin görseli eklenmiştir. Böylece çocukların paketin görseline birkaç saniye maruz kalmasına olanak verilecek şekilde bir tasarım uygulanmıştır. Bu tanıtım/reklâm filmi, "IRL Learn Colors with M\&M's Candy for Children Toddlersand Babies, Kids Pretend Play" adlı 3 dakika 1 saniye süren bir filmdir. Deneysel serimde kullanılacak olan ürün, ürünün reklâm filmi ve çizgi film belirlendikten sonra okullarla görüşmeler yapılmış ve gerekli izinler alınmıştır. Araştırmanın materyalleri hazırlanmış ve standa koyulacak ürünler satın alınmıştır. Reklâm filmi izletilen ürün dışındaki diğer ürünler, çocukların marketlerde gördükleri ve televizyonda reklâmına sık sık maruz kaldıkları ürünler arasından seçilmiştir. Burada amaç, reklâmın çocuklarda ürün satışına etkisinin daha net olarak anlaşılmasını sağlamaktır. Bu ürünlerin seçiminde, ambalajın çekiciliğinin bir fark yaratmaması için M\&M's draje şeker paketine yakın, sarı renkli paketleri olan ürünler (Ülker Dankek, Ülker Halley ve Eti Cin) özellikle tercih edilmiştir.

İkinci aşama ise deney sürecidir. Deney sırasında, çocukların kendilerini güvende hissetmeleri için alışık oldukları ortamda kalmaları tercih edilmiştir. Deney aşamasında, araştırmacı ve yardımcısı anaokulu sınıfına drama eğitmeni olarak girmekte ve öğrencilere kendilerini tanıtarak birazdan bir film izleyeceklerini sonra da alışveriş oyunu oynayacaklarını anlatmaktadırlar. Bu süreçte, deney grubuna, pedagogların yardımıyla seçilmiş 3 dakikalık çizgi film ve araştırmacı tarafından kurgulanmış 3 dakikalık bir reklâm filmi izletilmektedir. Kontrol gurubuna ise sadece deney grubuna izletilen çizgi film izletilmiştir. (Bkz. Resim $1)$.

Ardından her öğrenciye bir adet (5TL) sahte para verilerek sıraya girmeleri, birazdan binanın içine açılan bakkaldan alışveriş yaparak sadece bir adet ürün satın alma haklarının olduğu anlatılmıştır. Binada alışveriş yeri olarak kurulan stantta, daha önce araştırmacı tarafından belirlenen ve satın alınan Ülker Dankek, Ülker Halley, Eti Cin ve deney grubuna reklâmı izletilen M\&M's draje şeker bulunmaktadır. Çocukların birbirlerinden etkilenmemeleri için iki grupta da bulunan her çocuk, standın olduğu alana tek tek alınmış ve aldıkları ürünler siyah renkte poşetlere konulmuş ve çocuklara etkinlik bitene kadar aldığı ürünü kimseye göstermemesi gerektiği anlatılmıştır.

Çocuk alışveriş yaparken, araştırmacı da çocuğu gözlemleyerek aldığı ürünü not etmiştir. Çocuk bir ürün seçip aldığında, satıcı rolündeki kişi ürünü poşete koyarak çocuğa vermiştir. Alışverişini tamamlayan çocuk, bir başka odaya alınmış diğer arkadaşlarının alışverişlerini bitirmesini beklemiştir. Bu şekilde deney süreci tamamlanmıştır. 
Resim 1: Deneye Ait Görseller
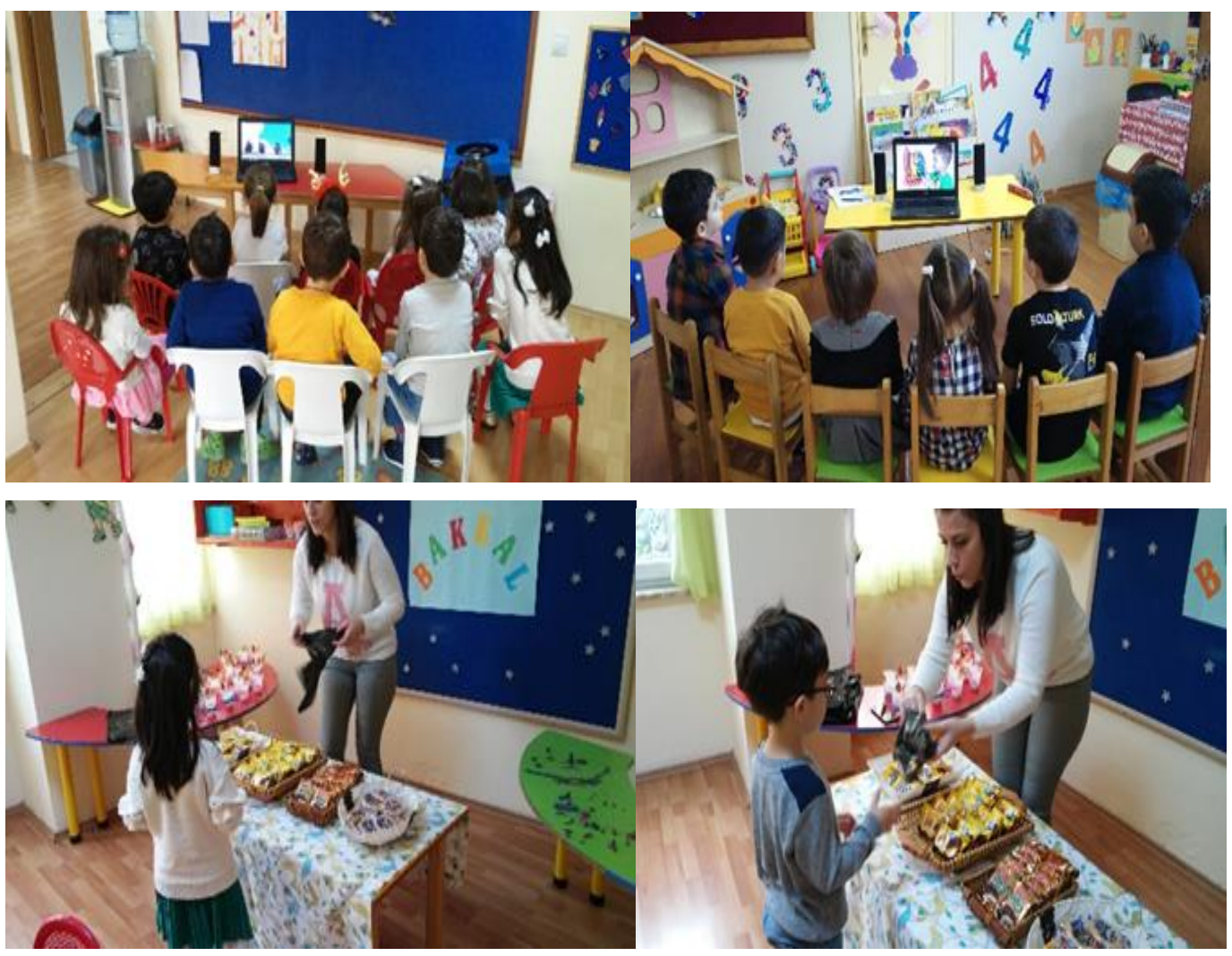

Veriler 10 Ocak 2018 ile 16 Şubat 2018 tarihleri arasında Trabzon'da bulunan 6 okulda toplanmıştır.

Araştırma kapsamında, reklâmı izleyen grubun reklâmda yer alan ürünü alıp almayacağı ve bu konuda iki grup arasında anlamlı fark olup olmadığı yapılan çeşitli analizlerle ortaya konmaya çalışılacaktır.

Araştırma verileri toplanırken çocukların deney grubunda mı yoksa kontrol grubunda mı yer aldıkları ve reklâm filmini izleyenlerle izlemeyenlerin ayrı ayrı olarak hangi ürünleri satın aldıkları kayıt altına alınmıştır. Buradan da görülebileceği gibi toplanan tüm veriler nonparametrik niteliktedir. Nonparametrik nitelikteki verilere sadece nonparametrik testler uygulanabileceğinden bu çalışmada deney grubu ile kontrol grubu arasındaki farkların ortaya koyulmasında Chi- Square (Ki-Kare) analizinden faydalanılmıştır. Verilerin analizinde 16.0 SPSS programı kullanılmıştır.

Araştırmanın hipotezleri şunlardır:

$\mathrm{H}_{0}$ : Bir ürünü satın alma ile o ürünün reklâmını izlemiş olma arasında anlamlı bir ilişki yoktur.

$\mathrm{H}_{1}$ :Bir ürünü satın alma ile o ürünün reklâmını izlemiş olma arasında anlamlı bir ilişki vardır. 


\section{Bulgular}

Deneysel serim yönteminin kullanıldığı bu çalışmada, toplam 209 çocuğa deney uygulanmıştır. Aşağıdaki tabloda (bkz. Tablo 1) deneyin uygulandığı 4-6 yaş arasındaki çocukların genel bilgileri verilmiştir. Bu çocuklardan 95'i kız, 114'ü erkektir. Çalışılan okul türlerine bakıldığında ise çocukların \%74'ünün devlet okullarına, \%26'sının ise özel okullara devam ettiği görülmektedir. Deneyin uygulandığı 209 çocuğun \%49'u deney grubunda, \%51'inin de kontrol grubunda yer aldığ 1 görülmektedir.

Tablo 1: Deneklerin Genel Bilgileri

\begin{tabular}{|l|c|c|l|c|c|l|c|c|}
\hline Cinsiyet & S & $\%$ & Okul Türü & S & $\%$ & $\begin{array}{l}\text { Hangi Gruba } \\
\text { Dâhil Olduğu }\end{array}$ & S & $\%$ \\
\hline Kız & 95 & 45 & Devlet & 154 & 74 & Deney & 102 & 49 \\
\hline Erkek & 114 & 55 & Özel & 55 & 26 & Kontrol & 107 & 51 \\
\hline Toplam & 209 & 100 & Toplam & 209 & 100 & Toplam & 209 & 100 \\
\hline
\end{tabular}

Araştırma yönteminin gerekliliği ve değişkenlerin manipüle edilmemesi için deney ve kontrol grubunda yer alacak çocuklar tesadüfi olarak belirlendiğinden sayılarının eşit olmadığı görülmektedir.

Deney toplam 6 okulda 209 çocuk üzerinde uygulanmıştır. Bu 209 çocuğun 95'i (\%45) kız, 114'ü (\%55) ise erkektir. Daha önce de açıklandığı gibi, deney sırasında kız ve erkek çocuklarının aldıkları ürünler kayıt edilemediğinden, kız ve erkek çocukların reklâmdan etkilenme ve satın alma davranışlarında bir fark olup olmadığına dair bir bilgi edinmek mümkün olmamıştır. Araştırma, devlet anaokulları, kolej anaokulları ve kreş olmak üzere 3 farklı okul türünde yapılmıştır. Fakat kreş ve kolejler özel işletmeler olduğu için özel okul başlığında verilmiştir. Uygulamanın yapıldığı 6 okuldan 3'ü özel okul, 3'ü de devlet okuludur. Devlet okullarındaki öğrenci mevcutlarının çok olması iki okul türü içerisinde sayısal olarak dengesizliğe sebep olmuştur. Araştırmaya katılan çocukların 154 (\%74) tanesi devlet okullarında, 55 (\%26) tanesi de özel okullarda eğitim görmektedir. Deneyin yapıldığı toplam 209 çocuk, daha önce de belirtildiği gibi deney ve kontrol gruplarına tesadüfi olarak atanmıştır. Deney grubunda 102 (\%48.8), kontrol grubunda ise 107(\%51.2) çocuk yer almıştır. Dolayısıyla, 102 çocuk hem çizgi filmi hem de reklâm filmini izlerken, 107 çocuk ise sadece çizgi filmi izlemiş reklâm filmini izlememiştir. Ürünü satın alırken, 36 tanesi (\%35.3) farklı ürünler almayı tercih etmişlerdir. Kontrol grubunda yer alan ve reklâm filmini izlememiş olan 107 çocuk içerisinden 43 tanesi (\%40.2) reklâmdaki ürünü 
almıştır. Bu grupta geriye kalan 64 (\%59.8) çocuk ise diğer ürünler arasından tercih yapmıştır.

Araştırma analiz kısmında, deney grubunda olup reklâmı izleyen çocuklarla kontrol grubunda olup reklâmı izlemeyen çocuklar arasında satın alma davranışında anlamlı bir fark olup olmadığını anlamak için Ki-kare testi yapılmıştır.

Tablo 2: Reklâm İzleyenlerle İzlemeyenlerin Satın Alma Davranışları Arasındaki Farkın Test Edilmesi: Ki-kare Analiz Sonuçları

\begin{tabular}{|c|c|c|c|c|c|c|}
\hline \multirow{2}{*}{$\begin{array}{l}\text { Reklâm } \\
\text { İzleme }\end{array}$} & \multicolumn{2}{|c|}{ Ürün Alma } & \multirow[t]{2}{*}{ Toplam } & \multirow{2}{*}{$\begin{array}{l}\text { Chi- } \\
\text { square }\end{array}$} & \multirow[t]{2}{*}{$\mathrm{df}$} & \multirow[t]{2}{*}{$\mathrm{p}$} \\
\hline & Alan & Almayan & & & & \\
\hline İzleyenler & $66(\% 31.6)$ & $36(\% 17.2)$ & $102(\% 48.8)$ & \multirow{7}{*}{12,581} & \multirow{7}{*}{1} & \multirow{7}{*}{.000} \\
\hline $\begin{array}{l}\% \text { within } \\
\text { izleme }\end{array}$ & 64.7 & 35.3 & 100.0 & & & \\
\hline İzlemeyenler & $43(\% 20.6)$ & $64(\% 30.6)$ & $107(\% 51.2)$ & & & \\
\hline $\begin{array}{l}\% \text { within } \\
\text { izleme }\end{array}$ & 40.2 & 59.8 & 100.0 & & & \\
\hline \multirow{3}{*}{ Toplam } & 109 & 100 & 209 & & & \\
\hline & $(\% 52.2)$ & $(\% 47.8)$ & $(\% 100)$ & & & \\
\hline & 52.2 & 47.8 & 100 & & & \\
\hline
\end{tabular}

Analiz sonucunda, reklâmı izleyen çocukların \% 64,7'sinin reklâmda izledikleri ürünü satın aldığı ve \%35,3'ünün ise reklâmdaki ürünü satın almadığı görülmektedir. Reklâm filmini izlememiş olan çocukların ise \%40,2'sinin M\&M's ürününü satın aldığ 1 ve \%59,8'inin ise M\&M's satın almadığ 1 görülmektedir. Bir başka ifadeyle ürünü satın alanların \%60,6'sı reklâmı izleyen deney grubunda yer alırken \%39,4'ü reklâmı izlemeyen kontrol grubunda bulunmaktadır. Analizin sonuçları da ayrıntılı bir şekilde göstermektedir ki, reklâma maruz kalan çocukların, reklâmdaki ürünü satın alma olasılığı, reklâma maruz kalmayan çocukların bu ürünü satın alma olasılığına göre, anlamlı derecede yüksektir. Üstelik sonuçlar, istatistiksel olarak da anlamlıdır $\left(\mathrm{x}^{2}(1)=12,581, \mathrm{p}=.00<.05\right)$. Analiz sonucunda $\mathrm{p}$ değeri 0,05 'den küçük olduğu için $\mathrm{H}_{0}$ reddedilerek, $\mathrm{H}_{1}$ kabul edilmiştir. Dolayısıyla, bir ürünün satın alınmasıyla o ürünün reklâmının izlenmiş olması arasında anlamlı bir ilişki olduğu görülmektedir.

Analiz sonucunda $\mathrm{p}$ değeri 0,05 'den küçük olduğu için $\mathrm{H}_{0}$ reddedilerek, $\mathrm{H}_{1}$ kabul edilmiştir. Dolayısıyla, bir ürünün satın alınmasıyla o ürünün reklâmının izlenmiş olması arasında anlamlı bir ilişki olduğu görülmektedir. 


\section{Sonuç ve Öneriler}

Bu çalışmada, reklâmın 4-6 yaş arasındaki anaokulu çocuklarında satın almaya yönelik etkisi incelenmiştir. Elde edilen bulgular, bu alandaki geçmiş bulgularla benzerlik göstermektedir. Keza reklâma maruz bırakılan 102 çocuktan 66'sının (\%64,7) reklâmın etkisiyle reklâmdaki ürünü tercih etmesi, geçmiş çalışmaları destekleyen bir sonuç olmuştur (Brody vd., 1981). Tıpkı Goldberg ve diğerlerinin 1978'de yaptığ çalışmada reklâmı izleyen çocukların reklâm etkisiyle şekerli ürünleri tercih etmesinde olduğu gibi bu çalsşmada da, reklâmı izleyen çocuklar tezgâhtaki ürünler arasından reklâmdaki ürünü almayı tercih etmişlerdir. $\mathrm{Bu}$ durum, muhtemelen reklâmın çocuklar üzerinde bıraktığı etki sonucunda olmuştur. Roedder ve diğerlerinin 1983 'de yaptığı çalışma da bunu desteklemektedir. Çocukların televizyon reklâmlarından ne düzeyde etkilendiklerini ortaya koymak amacıyla yaptıkları çalışmada araştırmacılar, 5-8 yaş ve 9-13 yaş aralığındaki iki farklı gruba yeni bir ürünü tanıtan reklâm filmi izletmişlerdir. Çocuklardan bu ürününün bulunduğu kategorideki diğer ürünler ve bu yeni ürün hakkındaki düşüncelerini belirtmeleri ve ürünler arasından tercihte bulunmaları istenmiştir. 9-13 yaş grubundaki çocuklar seçimleri sırasında reklâmı yapılan ürüne yönelik fazla tercihte bulunmazken, 5-8 yaş grubundaki çocuklar tercihlerini reklâmını izledikleri üründen yana kullanmışlardır. Araştırmacılar iki grup arasındaki farkın çocukların bilişsel gelişim düzeylerinin aynı olmamasından dolayı oluştuğunu belirtmişlerdir. Bu çalışma da okul öncesi çocuklarla yapıldığı için, bilişsel gelişim düzeyini tamamlamamış çocuklar reklâmdan yüksek oranda etkilenmişlerdir. Yaşları küçük çocukların televizyon programları ile reklâmlar arasındaki farkı anlayıp anlayamadıkları hala alanda tartışılmasına rağmen, bu çalışmanın uygulanması aşamasında da görülmüştür ki, 4-6 yaş arasındaki çocuklar çizgi film ile reklâm filmini birbirinden ayırt edebilmiştir. Deney grubunda yer alan çocukların çizgi filmi izlerken gözlenen rahat halleri reklâm filmini izlerken daha gergin ve dikkatli bir hal almıştır. Reklâmı izlerken bazı yerlerde çocukların ürünü anlamaya çalışıp "Aaa o ne?" , "Ben bundan hiç yemedim." ya da "Ben bunu biliyorum, annem almışt.." gibi tepkiler verdikleri görülmüştür. Bu çocukların reklâmın asıl amacını anlamasalar da çizgi film ile reklâmı ayırt edebildiklerini göstermektedir. Stephens ve diğerlerinin (1982) okul öncesi çocuklar üzerinde uyguladığı deneyde, çocukların televizyon programları ile reklâmları ayırt etmede \%82 oranında doğru cevap vermeleri sonucu ile örtüşmektedir. Kapferer de 5-6 yaş grubundaki çocukların büyük çoğunluğunun, reklâmları programlardan ayırabildiğini ifade etmiştir. Fakat kasıtlı olarak reklâm dışı hava verilen ve bir çizgi film sunulan reklâmlarda çocukların kafasının karışabildiğini de eklemiştir (1985: 56). Araştırma sonuçlarına göre reklâmı izleyen deney grubunun \%35.3'ü reklâmdaki ürünü almamış ve tezgâhta bulunan diğer ürünleri almayı tercih etmiştir. Bu durum birçok faktörden kaynaklanabilir. Reklâmı izletilen ve sonrasında tezgâhta sunulan deney ürününün daha önce çocukların çok fazla bilmediği, reklâmına maruz kalmadığı ve marketlerde çok sık karşılaşmadığı bir ürün olarak seçilmesi, deneyin içsel geçerliliğini yükseltse de 
bu noktada dezavantaj yaratmış olabilir. Çünkü çocuklar satın alma aşamasında hiç bilmedikleri deney ürününü almak yerine tadını daha önce bildikleri ürünler arasından birini seçmeyi tercih etmiş olabilirler. Bu faktörün yanında, tezgâhta bulunan diğer ürünlerden birini çok sevmesinin, ürünün çeşidinin ve ürünün boyutunun da etkili olduğu görülmüştür. Çocuklara yönelik reklâmların amacının, onların tercihlerini etkileyerek belli bir ürün veya markayı almaya ya da istemeye yönlendirmek olsa bile çocukların satın almaya yönelmesinde tek etkenin reklâm olmadığını ifade eden Kapferer, reklâmın yanında ürünü mağazada görmenin, ailenin ve arkadaşlarının görüşlerinin de önemli olduğunu vurgulamaktadır (1985: 141). Bu araştırmadan elde edilen gözlemler de bu durumu doğrulamaktadır.

Araştırmada kontrol grubunda yer alan 107 çocuktan 43'ünün $(\% 40,7)$ deney ürününün reklâmını görmediği halde tercih etmesinde de başka faktörler etkili olmuş olabilir. Bu faktörlerden en önemlisinin deney ürünü ambalajı olduğu düşünülmektedir. Deney ürününün ambalajının daha canlı renklerde olması ve ambalaj üzerinde içindeki şekerlerin görselinin bulunması çocukları etkilemiştir. Bilindiği gibi ambalaj tüketicinin satın alma kararlarına etki eden önemli bir faktördür. Literatüre bakıldığında bu konuda Ülger'in (2016) yaptığı çalışma dikkat çekmektedir. Ülger, okul öncesi çocuklarla yaptığı çalışmasında ambalajın çocukların tercihleri üzerindeki etkisini anlamaya çalışmış, paketler üzerindeki çizgi film karakterlerinin öğrencilerin satın alma tercihlerindeki etkisine odaklanmıştır. Çalışmasında çocukları iki farklı gruba ayırarak birine reklâm izletmiş, diğerine izletmemiş ve sonrasında her iki gruba da ürünler sunmuştur. Çalışmanın sonucunda reklâmın yer aldığı videoyu izleyen öğrencilerin de reklâmı izlemeyen öğrencilerin de üzerinde çizgi film karakterinin bulunduğu ürünü tercih ettikleri görülmüştür. Bu çalışmada da özellikle kontrol grubunda yer alan çocukların tezgâha gelip ürünleri gördüklerinde kısa süreli kararsızlıklar yaşadıkları ve içlerinden bazılarının deney ürününe yönelerek satın aldıkları görülmüştür. Deney sonrası kontrol gurubundan bu ürünü tercih eden çocuklara neden o ürünü aldığı sorulmuş, çocuklardan "Bu daha güzel görünüyor.", "Çünkü bu şeker." ya da "Bunu hiç yemedim." gibi cevaplar alınmıştır. Bu cevaplar da göstermektedir ki, çocuklar o ürünü bilmemelerine ve reklâmını hiç izlemeyen grupta olmalarına rağmen, ambalajın görünüşünden şeker olduğunu anlamışlar ve ambalajın görünüşünden etkilenmişlerdir. Ayrıca merak duygusu da çocukları satın almaya yönlendirmiştir.

$\mathrm{Bu}$ çalışmanın kısıtlarından bahsetmek gerekirse, ilk kısıt, çalışmada kolayda örneklem yöntemi kullanılmıştır ve bilindiği gibi kolayda örneklem yönteminden elde edilen sonuçlar genellenememektedir. Bu nedenle gelecekteki çalışmalarda tesadüfi örnekleme yöntemini kullanacak çalışmaların daha sağlam bulgular elde edeceği öngörülmektedir.

Araştırmanın ikinci kısıtı ise, çalışmanın yöntemidir. Bilindiği gibi, deneysel serimlerde deney ortamının dış dünyadan izole olması, dış dünyayı tam olarak 
yansıtamamasına sebep olmaktadır. Bu açıdan aynı konuyu farklı yöntemlerle ele alacak çalışmaların diş geçerliliğinin daha yüksek olacağı düşünülmektedir.

$\mathrm{Bu}$ çalışmada test edilen ürün grubunun sadece gıda ürünlerinden oluşması, çalışmanın bir diğer kısıtıdır. Literatüre bakıldığında çocukların oyuncak reklâmlarına ilgisi ve satın alma istekleri ile ilgili bulgular mevcuttur (Goldberg ve Gorn, 1974). Gelecekte yapılacak çalışmalarda farklı ürün gruplarıyla çocuklar üzerindeki reklâmın satın alma davranışına etkileri test edilebilir.

Araştırmanın dördüncü kısıtı ise, deneyin sadece 4-6 yaş arasındaki okul öncesi çocuklar üzerinde uygulanmış olmasıdır. Çalışmanın gelecekte çocuk pazarını temsil eden farklı yaş grupları üzerinde test edilmesi, pazarı tanımak adına oldukça faydalı olabilir.

Ayrıca bu çalışma Trabzon'daki çocuklar üzerinde uygulanmıştır. Gelecek çalışmalarda, aynı çalışmanın daha geniş ve farklı coğrafyalarda tekrarlanması bulguların karşılaştırılmasına imkân verecektir.

Araştırmanın son kısıtı, uygulamanın yapıldığı okul yöneticilerinin haklı koruyucu tutumları dolayısıyla oluşmuştur. Çocukların yaşları ve hangi ürünü satın aldığının dışında hiçbir bilginin kayıt altına alınmasına müsaade etmemeleri sonucunda kız ve erkek çocukların satın alma davranışları ve aldıkları ürünler kayıt altına alınamamıştır. Oysaki literatürde kız ve erkek çocukların satın alma davranışlarının birbirinden farklı olduğunu gösteren çalışmalar mevcuttur (Badur, 2007). Bu nedenle gelecekteki çalışmalarda kız ve erkek çocukların satın alma davranışlarının ayrıca incelenmesi yerinde olacaktır. Yine aynı sebepten, özel okul ve devlet okuluna devam eden çocuklarla çalışılmasına rağmen aradaki sosyo-ekonomik durumu değerlendirme olanağı olmamıştır. Gelecekteki çalışmalar bu değişkeni de dâhil ederek daha sağlıklı sonuçlar elde edebilirler.

Gözlem sırasında alınan notlara dayanarak çocukların satın alma davranışlarında ambalajın da etkili olduğu düşünülmektedir. Reklâmı izletilen M\&M's ürününün ambalajı diğer ürünlere göre daha canlı renklerdedir. Ayrıca paketinin üzerinde içindeki şekerlerin görselleri de bulunmaktadır. Bu ürün ambalajından dolayı çocuklara daha çekici gelmiş ve reklâmı izlemeyen kontrol grubundaki çocuklardan \%40,2 sinin ürünü satın almasına sebep olmuş olabilir. Gelecekteki çalışmalarda satın alma davranışı üzerindeki etkileri bağlamında ambalaj konusu ele alınabilir.

$\mathrm{Bu}$ çalışmada deneysel serim yönteminden faydalanılmış ve çocuklar deney sırasında gözlemlenmiştir. Yani bu çalışma reklâmın okul öncesi çocuklarda satın alma davranışına etki etmesi durumuna sadece çocuklar tarafından bakmıştır. Daha kapsamlı bir şekilde bu konuda, ebeveynlerin ve öğretmenlerin görüşleri de çalışmaya dâhil edilebilir. Araştırma sonucunda ve literatürde de belirtildiği gibi 8 yaşın altındaki çocuklar bilişsel gelişim düzeylerinden dolayı reklâma karşı savunmasızdırlar (Kapferer, 1985; John, 1999). 
Genel bir değerlendirme yapılması gerekirse, bu çalışmada yer alan 4-6 yaş grubundaki çocukların reklâmın satış amacını kavrayamadığı ve reklâmda gördügü her şeyi gerçek olarak algıladığı gözlemlenmiştir. Özellikle reklâma maruz kalan çocukların, dış etkilerden soyutlanmış özgür bir ortamda satın alma davranışı gerçekleştirdiğinde daha önce bilmediği ve tatmadığı ürünü çok rahat bir şekilde aldığı görülmüştür. Ayrıca çocukların reklâmı izlerken verdiği şekerli gıdaların çok tüketilmemesi ile ilgili tepkiler, satın alma evresinde tamamen öteledikleri bir bilgi olmuştur. Çocukların gün içinde çok fazla reklâma maruz kaldıkları düşünüldüğünde reklâm içeriklerinin hassas bir şekilde oluşturulması ve denetlenmesi gerektiği çok açıktır.

Reklâmların, çocukların besin tercihlerini olumsuz yönde etkilediği ve yiyecekler konusunda tüketim alışkanlıklarını da oldukça etkilediği birçok çalışma tarafından ortaya koyulmuştur (Lewis ve Hill, 1998; Borzekowski ve Robinson, 2001; Halford vd., 2004; Halford vd., 2007; Boyland ve Halford, 2013). Çocukların, artan obeziteden korunması, sağlıklı kalmaları ve bilinçli tüketiciler olarak yetişebilmeleri için, özellikle çocuklara yönelik reklâmlarda ilgili mercilerin yiyecek reklâmları içeriklerini denetlemesi gerektiğini vurgulamakta fayda vardır. Ayrıca reklamcıların da çocuklara yönelik reklâmlar üretirken hassas davranmaları gerekmektedir. Tabi ki bu nokta da görev düşenlerden biri de annebabalardır. Aileler çocuklarına reklâmların asıl amacı konusunda bilgi verebilir, sağlıklı yiyecekler tüketmeleri konusunda onları uyarabilir ve en önemlisi de bilinçli tüketim konusunda çocuklarını yönlendirebilirler.

Reklâmın tüm tüketiciler üzerinde etkili olduğu ve tüketicilerin tüketim alışkanlıklarını etkilediği, onları tüketime dolayısıyla da satın almaya yönlendirdiği bilinmektedir. Bu çalışmada vurgulanmak istenen, tüketici olarak sosyalleşme sürecinde var olan çocukların ve özellikle de bilişsel gelişim düzeyleri nedeniyle okul öncesi çocukların üzerinde reklâmın ne kadar etkili olduğu ve onları satın alma davranışı konusunda nasıl etkilediğidir. Bu çalışmada elde edilen analiz bulguları 1şığında, okul öncesi çocuklarda reklâmın satın alma davranışlarını etkilediği sonucunu ortaya koymuştur.

Reklâmların okul öncesi çocukların satın alma davranışı üzerinde etkili olduğunu, Türkiye'de ilk kez deneysel yöntem kullanarak ortaya koyan bu çalışmanın bulgularının, bu alanyazında çalışan bilim insanlarına, pazarlamacılara ve reklâmcılara katkı sağlaması beklenmektedir. 
Kaynakça

Adler, R. (1977). Research on the effects of television advertising on children; a review of the literature and recommendations for future research. Published Research Report. National Science Foundation, Washington, USA.

Aitken, P. P., Leathar, D. S., O'Hagan, F. J. ve Squair, S. I. (1987). Children's awareness of cigarette advertisements and brand imagery. Addiction, 82(6), 615-622.

Aktaş Arnas, Y. (2006). The effects of television food advertisement on children's food purchasing requests. Pediatrics International, 48(2), 138-145.

Atkin, C. (1975). The effects of television advertising on children: parent-child communication in supermarket breakfast cereal selection. Final report.

Badur, F. (2007). Televizyon reklâmlarının çocukların marka farkındalığı üzerindeki etkisi: yiyecek ve içecek reklâmları üzerine bir uygulama. Yayınlanmamış Yüksek Lisans Tezi, Atatürk Üniversitesi-Sosyal Bilimler Enstitüsü.

Bakir, A., Palan, K. M. ve Kolbe, R. H. (2013). A comparative content analysis of advertising practices to children. Journal of Current Issues\&Research in Advertising, 34(2), 247-262.

Bakir, A. ve Palan, K. M. (2010). How are children's attitudes toward ads and brands affected by gender-related content in advertising. Journal of Advertising, 39(1), 35-48.

Borzekowski, D. L. ve Robinson, T. N. (2001). The 30-second effect: an experiment revealing the impact of television commercials on food preferences of preschoolers. Journal of the American Dietetic Association, 101(1), 42-46.

Boyland, E. J. ve Halford, J. C. (2013). Television advertising and branding. effects on eating behaviour and food preferences in children. Appetite, 62, 236-241.

Brody, G. H., Stoneman, Z., Lane, T. S. ve Sanders, A. K. (1981). Television food commercials aimed at children, family grocery shopping, and mother-child interactions. Family Relations, 435-439.

Burr, P. L. ve Burr, R. M. (1977). Parental responses to child marketing. Journal of Advertising Research,17(6), 17-20.

Butter, E. J., Popovich, P. M., Stackhouse, R. H. ve Garner, R. K. (1981). Discrimination of television programs and commercials by preschool children. Journal of Advertising Research, 21 (2), 53-56.

Büyükbaykal, G. (2007). Televizyonun çocuklar üzerindeki etkileri. Ístanbul Üniversitesi İletişim Fakültesi Dergisi, (28), 31-44. 
Chernin, A. (2008). The effects of food marketing on children's preferences: testing the moderating roles of age and gender. The ANNALS of the American Academy of Political and Social Science, 615(1), 101-118.

Clancy-Hepburn, K., Hickey, A. A. ve Nevill, S. (1974). Children's behavior responses to tv food advertisements. Journal of Nutrition Education and Behavior, 6(3), 93-96.

Connor, S. M. (2006). Food-related advertising on preschool television: building brand recognition in young viewers. Pediatrics, 118(4), 1478-1485.

Ertunç, F. (2011). Çocuk dünyasında reklâmın rolü: televizyon reklâmlarında çocuklara yönelik düzenlemeler. Uzmanlık Tezi, Radyo ve Televizyon Üst Kurulu.

Farooq, A. J. (2010). Impact of advertisement on children behavior: evidence from Pakistan. European Journal of Social Sciences, 12(4), 663-670.

Goldberg, M. E. ve Gorn, G. J. (1974). Children's reactions to television advertising: an experimental approach. Journal of Consumer Research, 1(2), 69-75.

Goldberg, M. E., Gorn, G. J. ve Gibson, W. (1978). TV messages for snack and breakfast foods: do they influence children's preferences?. Journal of Consumer Research, 5(2), 73-81.

Gorn, G. J. ve Florsheim, R. (1985). The effects of commercials for adult products on children. Journal of Consumer Research, 11(4), 962-967.

Gorn, G. J. ve Goldberg, M. E. (1977). The impact of television advertising on children from low income families. Journal of Consumer Research, 4(2), 8688 .

Guran, T., Turan, S., Akcay, T., Degirmenci, F., Avci, O., Asan, A. ve Bereket, A. (2010). Content analysis of food advertising in Turkish television. Journal of Paediatrics and Child Health, 46(7-8), 427-430.

Günlü, Z. ve Derin, D. (2012). Televizyon reklâmlarının okul çağı çocuklarının besin seçimi üzerine etkilerinin bir incelemesi. Selçuk Üniversitesi İletişim Fakültesi Akademik Dergisi, 7(3), 62-77.

Halford, J. C., Gillespie, J., Brown, V., Pontin, E. E. ve Dovey, T. M. (2004). Effect of television advertisements for foods on food consumption in children. Appetite, 42(2), 221-225.

Halford, J. C., Boyland, E. J., Hughes, G., Oliveira, L. P. ve Dovey, T. M. (2007). Beyond-brand effect of television (TV) food advertisements/commercials on caloric intake and food choice of 5-7-year-old children. Appetite, 49(1), 263267. 
Hameed, A., Waqas, A., Aslam, M. N., Bilal, M. ve Umair, M. (2014). Impact of tv advertisement on children buying behavior. International Journal of Humanities and Social Science, 4(2), 246-261.

Jenkin, G., Madhvani, N., Signal, L. ve Bowers, S. (2014). A systematic review of persuasive marketing techniques to promote food to children on television. Obesity Reviews, 15(4), 281-293.

John, D. R. (1999). Consumer socialization of children: a retrospective look at twenty-five years of research. Journal of Consumer Research, 26(3), 183-213.

Kapferer, J. N. (1985). Reklâm ve çocuk, (Çev. Şermin Önder), İstanbul: Afa Yayınları.

Karaca, Y., Pekyaman, A. ve Güney, H. (2007). Ebeveynlerin televizyon reklâm içeriklerinin çocuklar üzerindeki etkilerini etik açıdan algılamalarına yönelik bir araştırma. Sosyal Bilimler Dergisi, 9(2), 233-250.

Kurt, E. ve Altun, T. (2014). Televizyon reklâmlarının ilkokul öğrencilerinin beslenme alışkanlıklarına etkisi üzerine bir inceleme. Akademik Sosyal Araştırmalar Dergisi,(7),393-408.

Kurtuluş, K. (2006). Pazarlama araştırmaları, İstanbul: Literatür Yayıncılık.

Levin, S. R., Petros, T. V. ve Petrella, F. W. (1982). Preschoolers' awareness of television advertising. Child Development, 933-937.

Lewis, M. K. ve Hill, A. J. (1998). Food advertising on British children's television: a content analysis and experimental study with nine-year olds. International Journal of Obesity, 22(3), 206-214.

McNeal, J. U. (1999). The kids market: mythsandrealities, Paramount Market Publishing.

McNeal, U. J. ve Yeh, Chyon-Hwa. (1997). Development of consumer behavior patterns among Chinese children. Journal of Consumer Marketing, 14(1), 4559.

Nakip, M. (2003). Pazarlama araştırmalarl, teknikler ve (SPSS destekli) uygulamalar, Ankara: Seçkin Yayıncılık.

Roedder, D. L., Sternthal, B. ve Calder, B. J. (1983). Attitude-behavior consistency in children's responses to television advertising. Journal of Marketing Research, 20(4), 337-349.

Šramová, B. ve Pavelka, J. (2017). The perception of media messages by preschool children. Young Consumers, 18(2), 121-140.

Stephens, N., Stutts, M. A. ve Burdick, R. (1982). Preschoolers' ability to distinguish between television programming and commercials. Journal of Advertising, 11(2), 16-26. 
Tokgöz, O. (1979). Televizyon reklâmları ve çocuklar. Ankara Üniversitesi Sosyal Bilimler Fakültesi Dergisi, 34(01), 93-110.

Tokuç, B., Berberoğlu, U. ve Ekuklu, G. (2009). Reklâm ve çocuklar: çocukların gıda markalarını tanıması, beslenme alışkanlıklarını ve gıda tercihlerini etkiliyor mu?. TAF Preventive Medicine Bulletin, 8(6), 459-464.

Ülger, B. (2016). Packages with cartoon trade characters versus advertising: an empirical examination of preschoolers' food preferences. Journal of Food Products Marketing, 15(1), 104-117.

Ünal, N. ve Durualp, E. (2012). Televizyonun okul öncesi çocuklar üzerindeki etkisi. Journal of Institute of Social Sciences, 3(2), 93 - 104.

Verma, D.P.S. ve Kapoor, N. (2004). Influence of tv advertisements on children's buying response: role of parent-child interaction. Global Business Review, 5(1), 51-71

Vodinalı, S. (2016). Tüketim kültürü bağlamında reklâm ve çocuklar üzerindeki etkileri: "Maret yoook mu?" reklâmı üzerine bir çözümleme. International Journal of Social Sciences and Education Research, 2 (1), 197-222. 